\title{
Rural School Leadership for Collaborative Community Development
}

\author{
Hobarat L. Harmon \\ Professional Consulting and Research Services
}

Kai Schafft

Pennsylvania State University

In this article we address the role of rural schools in community development. We first discuss the largely historical linkages between rural schools and the communities they serve, and what this means for both school and community well-being. We then consider the newly revised standards for preparing school administrators, developed by the Interstate School Leaders Licensure Consortium, and how these standards may align with community-building efforts. In sum, we argue that enlightened educational leadership that seriously takes into account the $21^{\text {st }}$ Century needs of students - as well as the communities in which they reside - cannot help but interpret academic and community improvement goals as mutually reinforcing priorities.

Can citizens of rural communities and the school board members they elect expect public schools to serve community development needs consistent with demands of the $21^{\text {st }}$ Century? The answer by most taxpayers who live in rural America would likely be "Yes." After all, the rhetoric by those who are selected to lead the school district and local schools seldom fails to acknowledge the benefits of a good school system in preparing youth for success in a competitive global economy. But in today's environment of high stakes accountability that emphasizes student test scores, district and school leaders may demonstrate little concern for collaborating in local community development efforts. How then can school board and community leaders be expected to determine if future district and school leadership will serve the needs of students and the community well?

In this article we address the role of rural schools in community development. We first discuss the largely historical linkages between rural schools and the communities they serve, and what this means for both school and community well-being. We then consider the newly revised standards for preparing school administrators, developed by the Interstate School Leaders Licensure Consortium (Council of Chief State School Officers, 2007), and how these standards may align with communitybuilding efforts. In sum, we argue that enlightened educational leadership that seriously takes into account the $21^{\text {st }}$ Century needs of students - as well as the communities in which they reside - cannot help but interpret academic and community improvement goals as mutually reinforcing priorities.

4 - The Rural Educator

\section{School-Community Linkage}

Advocating revitalization of rural areas by building and sustaining strong community linkages with local public schools is not a new idea. Many rural advocates have promoted the need for schools to "reform" in ways that build on the central role a school must play in the life of its community, as well as the individual student, if the school is to be a viable and highly valued local institution (Beaulieu \& Israel, 2005; Beaulieu \& Mulkey, 1995; Gibbs, 2005; Harmon, 1999, 2000; Hobbs, 1991; Howley, 1991; Miller, 1991, 1995; Sharratt, McClain, \& Zehm, 1993; Schafft, Alter, \& Bridger, 2006; Spears, Combs, and Bailey, 1990; Versteeg, 1993).

Numerous authors have reported on the importance of involving parents and/or the community in rural school improvement efforts, particularly in support of student academic achievement (Barley \& Beesley, 2007; Batt, 2008; Bauch, 2001; Harmon \& Dickens, 2004; Howley, Bickel, \& McDonough, 1997; Markell, 2000; Phelps, 2000; Prater, Bermudez, \& Owens, 1997; Wettersten et al., 2005). Additionally, researchers have reported district and school leaders may view parent and community interests or values primarily as barriers to improving student academic achievement (e.g., see Corbett, 2007, and Larson \& Howley, 2006). Budge (2006) reported that despite their portrayal of life in the rural area as a privilege, educational leaders viewed place (rurality) as presenting more problems than possibilities in the lives of most students.

Educational leaders may develop personal identities connected to a rural place, come to personally value the quality of rural life-ways, and build individual leadership

The Rural Educator 
characteristics consistent with the mentality of a small rural community. Yet, these leaders may still struggle with the tension between decisions of professional practice that prepare students for a prosperous future and decisions that address the community's need for the school to increase the viability of the rural place. Challenges from poverty and the continual loss of employment opportunities that pay a living wage may magnify this tension in many rural communities. Consequently, Budge (2006) maintained that a "critical leadership of place" may best address the strengths and challenges found in much of rural America:

A critical leadership of place is leadership that specifically aims to improve the quality of life in particular communities. Leaders with a critical leadership of place support community as a context for learning, understand that schools and their local communities are inextricably linked, and that the ability of each to thrive is dependent upon the other. They work to conserve what is beneficial to the well being of students, families, and communities, while actively leading efforts that address the challenges and/or contradictions found in the local context. (p. 8)

Leaders of school districts and schools in rural places need a clear vision of a mutually beneficial, collaborative school-community building process. Chance (1999) provided a rationale for why such a process is essential:

(The) level of mutual collaboration, and the degree of intensity, found between the school and the community directly reflects on the success of both. In truth, a collaborative school and community represent a 'greater' community. This greater community epitomizes people who share a common core of values regarding the young people of that community and their potential future. (p. 231)

Chance (1999) cautioned, however, that some rural schools and communities never realize the importance of nurturing or supporting such a collaborative relationship. Discovering the need to build such a relationship may be too late if it is recognized only “...because the school is being closed, the community is losing one of its primary businesses, or the community has declined to a level of ineffectiveness" (p. 233).

Arguably, factors such as rural economic decline, rural outmigration, school consolidation issues, and current state and federal education policies that measure school success solely based on student test scores may work against the potential for rural educational leaders to assume collaborative roles in promoting local community development.
Well-functioning schools help to increase the social integration of communities and neighborhoods by strengthening local identity and sense of commonly held purpose. Schools function as centers of community activity and nurture public participation in civic and community affairs. They also provide physical spaces that enable community members to come together as a community, for sporting events, theatrical productions, and school board meetings. Rural schools, in particular, serve as symbols of community autonomy, vitality, and identity. Given their essentially integrative and interactive nature, schools naturally tend to enhance a sense of collective identity and attachment to place, and thus have socially developmental outcomes.

Schools also provide economically integrative local roles. In rural areas, schools are often the principal source of local employment. Good schools represent important amenities for local areas that help to maintain or increase property values. Perhaps most obviously, schools produce human capital by educating cohorts of young people and providing them with skills and knowledge to become economically productive adults. Availability of human capital presents an asset to local businesses requiring a well-educated workforce and an incentive for new businesses to locate in the community (Gibbs, 2005).

Research shows significant community economic benefits associated with public schools. Based on a major review of the literature, Weiss (2004) concluded that public schools impact economic development in a number of ways. "On the national level, there is convincing evidence showing that public schools have a profound effect on national economic growth, influencing the quantity and quality of education. Human capital theory documents that investment in skill level of a nation's population translates into increased national productivity. Education also leads to higher wages and greater social opportunity” (Weiss, 2004, p. 31).

Weiss also found that many studies have shown that public schools and school spending impact state and local economies and can play a role in attracting business. By educating the future workforce, public schools help make state and localities more economically competitive. Public schools also are major employers that have a short-term stimulus impact on state and local economies, and the quality of public schools influence business site selection and labor location decisions. According to Weiss (2004), "In one aspect of local development, there is clear-cut, undisputed evidence: the quality of public schools directly influences residential property values. Homes in highperforming school districts sell for higher prices than homes in lower-performing school districts” (p. 31). Lyson's (2002) frequently cited study, for example, compared rural upstate New York municipalities containing schools with those lacking schools. Lyson based his work in part on earlier research investigating the relationship between local civic infrastructure and overall community well-being (see, e.g., Irwin, Tolbert \& Lyson, 1997, and Mills \& Ulmer, 
1946/1970) and found that communities with schools had higher housing values; higher percentages of professional, managerial and executive workers; greater entrepreneurial activity; higher percentages of residents working locally; and lower commuting times. He argued that "in communities where the citizenry is civically engaged, local businesses prosper, and...these factors anchor populations to place” (Lyson, 2002, p. 136). This was especially true for smaller rural communities.

\section{Future School Leaders}

Preparing effective educational leaders for rural communities is critically important. Almost 8,000 or more than half (56 percent) of all operating public school districts in the US are located in rural areas. These districts include approximately one-third (31 percent) of the nation's public schools and more than one-fifth (21 percent) of the total US student population. Over 10 million students are served by rural schools (Provasni, KewalRamani, Coleman, Gilbertson, Herring \& Xie, 2007).

If left unattended, however, community development is unlikely to garner the emphasis necessary in programs that prepare future leaders of rural schools and districts. Thinking globally and acting locally in ways that value rural places is not easy in a policy environment that seldom views community development as a traditional or essential role of schooling. Kretzmann and McKnight (1993) remind us:

As schools have become more professionalized and centralized, they have tended to distance themselves from their local communities. The vital links between experience, work, and education have been weakened. As a result, public and private schools in many rural and urban communities have lost their power as a valuable community resource. And many economically distressed towns, communities, and neighborhoods have begun to struggle toward economic revitalization without the valuable contributions of the local schools. (p. 2)

Similarly, one-size-fits-all preparation programs for school administrators - with the usual unspoken priority of serving the needs of urban schools-are not adequate for serving schools and their communities in rural areas (see, e.g., Chalker, 1999). Yet, there are rays of hope. The prevalent theme of serving all students in the current mandated school reform agenda clearly places a premium on adequate preparation of administrators. And both school system and community leaders are realizing their future success, perhaps survival, will depend less on "going it alone" strategies and more on building collaborative partnerships with old and new entities.

A starting point, we believe, is to embrace the newly revised standards for preparing school administrators
(Council of Chief State School Officers, 2007). The Interstate School Leaders Licensure Consortium (ISLLC) standards, first produced in 1996, were revised over a twoyear period and released in March 2008. Gene Wilhoit, executive director of the Council of Chief State School Officers (CCSSO) notes, "These policy standards are the foundation to building a comprehensive and cohesive leadership system that effectively recruits, supports, retains, and rewards high-quality leaders. . . . They give state and district leaders a guide for what to consider in gauging quality and monitoring and supporting improvement in educational leadership" (Council of Chief State School Officers, 2008, p.1). Adopted by the National Policy Board for Educational Administration, an array of education organizations, the Educational Leadership Policy Standards: ISLLC 2008 are, according to Wilhoit, the "first step toward creating comprehensive, locally tailored practice standards and other approaches for developing and retaining high-quality school leaders" (Council of Chief State School Officers, 2008, p.3).

The Educational Leadership Policy Standards: ISLLC 2008 organizes the functions that help define strong school leadership under six standards. These standards represent the broad, high-priority themes that education leaders must address in order to promote the success of every student. These six standards call for:

1. Setting a widely shared vision for learning;

2. Developing a school culture and instructional program conducive to student learning and staff professional growth;

3. Ensuring effective management of the organization, operation, and resources for a safe, efficient, and effective learning environment;

4. Collaborating with faculty and community members, responding to diverse community interests and needs, and mobilizing community resources;

5. Acting with integrity, fairness, and in an ethical manner, and;

6. Understanding, responding to, and influencing the political, social, legal, and cultural context.

The new policy standards are intended to shape and influence policy, as well as provide guidance to education and policy leaders at all levels about the traits, goals, and responsibilities of school and district leaders. Consequently, they have an inherent high value for preparing future leaders in rural school districts and schools. However, it will likely take considerable influence by educational policy makers at state and school district levels to ensure that the new ISLLC standards are interpreted and implemented in ways that reinforce the collaborative and symbiotic connections between rural schools and their communities. 
A new paradigm of thinking and action will be necessary in many educational administration/leadership programs to prepare superintendents and principals that can embrace community development as a role of the rural school (or district). Some ISLLC standards (i.e., 4 and 6) appear easily aligned with symbiotic school-community development goals. In Table 1 we provide an example question for each standard to initiate thinking regarding how to connect the standard and role of the rural school to worthy community development efforts. Moreover, school board members could use these standards and related community development questions as a starting point in preparing job announcements and interview protocols to solicit future leaders who understand the role of public education in fostering local community development interests.

\section{Table 1}

ISLLC Standards and Related Community Development Questions

\section{$\underline{\text { ISLLC Standard }}$}

1. Setting a widely shared vision for learning

2. Developing a school culture and instructional program conducive to student learning and staff professional growth

3. Ensuring effective management of the organization, operation, and resources for a safe, efficient, and effective learning environment

4. Collaborating with faculty and community members, responding to diverse community interests and needs, and mobilizing community resources

5. Acting with integrity, fairness, and in an ethical manner

6. Understanding, responding to, and influencing the political, social, legal, and cultural context

\section{Community Development Question}

How will the district or school leader gain the input and continuous support of key community leaders in setting and sharing the vision for student learning at the school?

How will the district or school leader encourage all school staff to become actively involved in the community as a means of professional growth for improving instructional effectiveness?

How will the district or school leadership collaborate with community organizations to ensure a safe and effective learning environment for all students?

What collaborative process will the district or school leader use in identifying community development needs that mutually accomplish goals of the school and community?

How will the district or school leader demonstrate integrity and fairness in collaborative community development activities that involve parents and multiple community organizations?

How will the district or school leader seek to understand the local rural culture in ways that influence positive school-community collaboration?
The questions provide a foundation for connecting educational leadership and community development. For example, school and district leaders who gain the input and continuous support of key community leaders in setting and sharing the vision for student learning (question 1) also gain perspectives on how students can be of service to the community while learning important life skills. Moreover, school and district leaders who encourage use of rural school facilities for "community functions" (e.g., voting precinct, community organization's fundraising dinner, family reunion, Cooperative Extension service meeting) demonstrate an understanding of the local rural culture in ways that influence positive school-community collaboration and community development (question 6).

The questions in Table 1 further reflect our belief that good rural schools are only possible where the community and schools share a responsibility and take collaborative actions that enhance the conditions necessary for all students to be successful-where community social capital serves the school and the school fosters a sense of place among students. 


\section{Conclusions}

Cultivating collaborative and meaningful schoolcommunity development will be a hallmark of good public schools that can meet the challenges facing rural communities and their students in the $21^{\text {st }}$ Century. Collaboration must extend beyond a singular focus on student achievement to a blended community and educational leadership strategy that takes as a fundamental assumption that ensuring the academic success of students, on the one hand, and the social and economic vitality of the rural community, on the other, are not mutually exclusive priorities, but are instead deeply and indeed inextricably connected. Consequently, the leadership selected to decide and guide well-meaning educational reform initiatives will be critical, particularly if the reform is to be sustained by local community resources.

Recent history, however, suggests that the evolving role of public schools in America is moving farther away from its most valuable lifeline of support-the public and local community. Serving the needs of nation building and global competitiveness seems to ring loud in the ears of policymakers, fostered by the impending lower standards of living that global competitiveness will bring to citizens who are educationally unprepared for change. Setting high standards for student achievement is an exemplary goal, if the drum beat to which school leaders, teachers and communities must march allows for genuine collaboration that serves the mutually beneficial goals of schools and communities.

Most communities in rural America face enormous challenges and change. A new crop of community and public school leaders will be needed as those of the "babyboomer" generation retire. The leadership bridge to foster collaborative community development has been constructed in some school districts. In many other areas of rural America, however, it is time to sound the alarm for a more genuine collaboration between schools and their communities.

Will leaders in public school districts react positively to this alarm and become better community and economic development partners? Or will these leaders hear the alarm as simply "noise" from the distant countryside, made by those perceived to not understand the role of public schools in an era of high stakes accountability for student success on state tests?

To both public education and community leaders, we emphasize the point made by editors of Challenges for Rural America in the Twenty-First Century:

The overall challenge ... is that rural areas will not succeed if they employ 'go it alone' strategies. Only through cooperation between communities, among interests within communities, and between local governments, NGOs, and the private sector will rural areas be able to prosper in the new millennium (Brown \& Swanson, 2003, p. 14).

Each rural community and its schools must share a responsibility and take collaborative actions that build community and strengthen positive results for all students to be successful-where community social capital serves the school and the school fosters a sense of place among students, regardless of where they ultimately chose to live.

\section{References}

Barley, Z A., \& Beesley, A.D. (2007). Rural school success: What can we learn? Journal of Research in Rural Education, 22(1), 1-16.

Batt, E.G. (2008). Teacher's perception's of ELL education: Potential solutions to overcome the greatest challenges. Multicultural Education, 15(3), 39-43.

Bauch, P.A. (2001). School-community partnerships in rural schools: Leadership, renewal, and a sense of place. Peabody Journal of Education, 76(2), 204-221.

Beaulieu, L., \& Israel, G.D. (2005). It's more than just schools: How families and communities promote student achievement. In L. Beaulieu and R. Gibbs (eds.), The role of education: Promoting the economic and social vitality of rural America (pp. 44-55), Mississippi State, MS: Southern Rural Development Center.

Beaulieu, L., \& Mulkey, D. (Eds.). (1995). Investing in people: The human capital needs of rural America. Boulder, CO: Westview Press.

Brown, D.L., \& Swanson, L.E. (Eds.). (2003). Challenges for rural America in the twenty-first century. University Park, PA: The Pennsylvania State University Press.

Budge, K. (2006, December 18). Rural leaders, rural places: Problem, privilege, and possibility. Journal of Research in Rural Education, 21(13).

Chalker, D.M. (Ed.). (1999). Leadership for rural schools: Lessons for all educators (pp. 231-242). Lancaster, PA: Technomic Publishing Company, Inc.

Chance, E.W. (1999). School-community collaborative vision building: A study of two rural districts. In D. M. Chalker (Ed.), Leadership for rural schools: Lessons for all educators (pp. 231-242).

Corbett, M. (2007). Learning to Leave: The irony of schooling in a coastal community. Nova Scotia, CA: Fernwood Publishing.

Council of Chief State School Officers. (2007). Educational leadership policy standards: ISLLC 2008 as adopted by the national policy board for educational administration on December 12, 2007. Washington, DC: Author.

Council of Chief State School Officers. (2008). Introduction to the educational leadership policy standards: ISLLC 2008. Washington, DC: Author. 
Gibbs, R. (2005). Education as a rural development strategy. Amber Waves, 3(5), 20-25.

Harmon, H.L. (1999). Creating work-based learning opportunities for students in rural schools, The High School Magazine, 6(6): 22-27.

Harmon, H.L. (2000). Linking school-to-work and rural development. FORUM for applied research and public policy, 15(1), 97-100.

Harmon, H.L., \& Dickens, B.H. (2004). Reaching out in rural districts. American School Board Journal, 191(8), 28-31.

Hobbs, D. (1991). Exemplary rural school programs in support of rural development. Symposium conducted at the National Conference on Rural Adult Education Initiatives, Kansas City, MO.

Howley, A., Bickel, R., \& McDonough, M. (1997). The call for parent involvement in rural communities: Mantra or mystification. Journal of Research in Rural Education, 13(2), 101-107.

Howley, C. (1991). The rural education dilemma as part of the rural dilemma: Rural education and economics. In A.J. DeYoung (Ed.) Rural Education: Issues and Practices (pp. 73-145). New York: Garland.

Irwin, M., Tolbert, C., \& Lyson, T. (1997). How to build strong home towns. American Demographics, 19(2), 42-47.

Kretzmann, J, \& and McKnight, J. (1993). Building communities from inside out: A path toward finding and mobilizing a community's assets. Chicago, IL: Assisting Christians to Act Publications.

Larson, W., \& Howley, A. (2006). Leadership of mathematics reform: The role of high school principals in rural schools. ACCLAIM Monograph No. 3. (ERIC Document Reproduction Service No. ED 498 435).

Lyson, T.A. (2002). What does a school mean to a community? Assessing the social and economic benefits of schools to rural villages in New York. Journal of Research in Rural Education, 17(3), 131137.

Markell, G. (2000). Rural communities matter: How PTAs can increase parent involvement in our nation's small towns. Our Children, 26(3), 3.

Miller, B. (1991). Rural Distress and survival: The school and the importance of community. Portland, OR: Northwest Regional Educational Laboratory.
Miller, B.A. (1995). The role of rural schools in community development: Policy issues and implications. Journal of Research in Rural Education, 11(3), 163-172.

Mills. C. W., \& Ulmer. M. (1946/1970). Small business and civic welfare (Report of the Smaller War Plants Corporation to the Special Committee to Study Problems of American Small Business, Document 135. U.S. Senate, 79th Congress, 2nd session, February 13). Washington, DC: U.S. Government Printing Office. (Reprinted in The Structure of Community Power, pp. 124-154, by M. Aiken \& P. Mott, Eds., 1970, New York: Random House).

Phelps, P. (2000). Creating a commitment to family involvement. The Rural Educator, 21(3), 35-38.

Prater, L., Bermudez, A. B., \& Owens, E. (1997). Examining parental involvement in rural, urban, and suburban schools. Journal of Research in Rural Education, 13(1), 72-75.

Provasni, S., KewalRamani, S., Coleman, M., Gilbertson, L., Herring, W., and Xie, Q., (July, 2007). Status of education in rural America (NCES 2007-040). Washington, DC.: National Center for Education Statistics, Institute of Education Sciences, U.S. Department of Education.

Schafft, K. A., Alter, T. R., \& Bridger, J. (2006). Bringing the community along: A case study of a school district's information technology rural development initiative. The Journal of Research in Rural Education, 21(8), 1-10.

Sharratt, G,. McClain, C., \& Zehm, S. (1993). Vocational education in rural America: An agenda for the 1990s. The Rural Educator, 14(1): 21-26.

Spears, J.D., Combs, L.R., and Bailey, G. (1990). Accommodating change and diversity: Linking rural schools to community. [A Report of the Ford Western Taskforce]. Manhattan, KS: Rural Clearinghouse for Lifelong Education and Development.

Versteeg, D. (1993). The rural high school as community resource, Educational Leadership, 50(7): 54-55.

Weiss, J.D. (2004). Public schools and economic development: What the research shows. Cincinnati, $\mathrm{OH}$ : KnowledgeWorks Foundation.

Wettersten, K. B., Guilmino, A., Herrick, C. G., Hunter, P. J., Kim, G. Y., Jagow, D., et al. (2005). Predicting educational and vocational attitudes among rural high school students. Journal of Counseling Psychology, 52(4), 658-663. 